\title{
IN VITRO SHOOT REGENERATION OF A CENTAUREA AMAENA BOISS. \& BALANSA - A CRITICALLY ENDANGERED AND ENDEMIC PLANT
}

\author{
UZUN, S. $.^{*}-$ EKINCI, E. ${ }^{1}-$ ÖZKATAN, H. ${ }^{1}-$ ATASAGUN, B. ${ }^{2 *}$ \\ ${ }^{I}$ Department of Field Crops, Agricultural Faculty, Erciyes University, 38039 Kayseri, \\ Turkey \\ ${ }^{2}$ Yeşilhisar Vocational School, The University of Kayseri, 38800 Kayseri, Turkey \\ *Corresponding author \\ e-mail: saticocu@yahoo.com; phone: +90-352-621-7939/38675; fax: +90-352-621-7989
}

(Received $18^{\text {th }}$ Oct 2019; accepted $30^{\text {th }}$ Jan 2020)

\begin{abstract}
This study was conducted to investigate in vitro regeneration potential of Centaurea amaena, a critically endangered and an endemic plant in Turkey. For this purpose, cotyledon, leaf and cotyledon node explants were cultured in Murashige and Skoog (MS) media supplemented with different concentrations of 6-benzylaminopurine (BAP; 1-4 $\mathrm{mg} \mathrm{L}^{-1}$ ), thidiazuron (TDZ; 0.3-1.2 $\mathrm{mg} \mathrm{L}^{-1}$ ) or metaTopolin $\left(m \mathrm{~T} ; 0.5-4 \mathrm{mg} \mathrm{L}^{-1}\right)$ with or without $0.5 \mathrm{mg} \mathrm{L}^{-1} \alpha$-naphthalene acetic acid (NAA). In axillary shoot regeneration experiments from cotyledon node explants, the greatest number of shoots per explant (9.975) was obtained from $4 \mathrm{mg} \mathrm{L}^{-1} m \mathrm{~T}$-containing MS media, which yielded a shoot regeneration frequency of $70.83 \%$. In indirect organogenesis experiments, the greatest number of shoots per explant in cotyledons (4.152 shoots/explant with the shoot regeneration frequency of 55.00\%) was obtained from $1 \mathrm{mg} \mathrm{L}^{-1} \mathrm{mT}$ containing media and the greatest number of shoots per explant in leaves (4.132 shoots/explant with the shoot regeneration frequency of 50.00\%) was obtained from $4 \mathrm{mg} \mathrm{L}^{-1} m \mathrm{~T}$-containing media. Only callus induction was observed in TDZ-containing media or combinations of TDZ concentrations with NAA. About $50.00 \%$ root formation was achieved from half-strength MS medium containing $2.0 \mathrm{mg} \mathrm{L}^{-1}$ indole3-butyric acid.
\end{abstract}

Keywords: axillary shoot regeneration, $B A P, m T$, organogenesis, $T D Z$

\section{Introduction}

Centaurea amaena Boiss. \& Balansa belonging to the Phalolepis section of the Compositae family is classified as CR B2ab (i,iii) based on IUCN criteria (Atasagun et al., 2013; Atasagun and Aksoy, 2018). The species occurs over the stony slopes of Y1lanlı Mountain, located between $38^{\circ} 38^{\prime}-38^{\circ} 41^{\prime} \mathrm{N}$ longitudes and $35^{\circ} 30^{\prime}-35^{\circ} 35^{\prime}$ $S$ latitudes to the west of Kayseri, Turkey and naturally grows in arid environments at altitudes of between 1.170-2.300 m (Atasagun and Aksoy, 2018). The species exists in two localities in Kayseri with distribution area of about $0.55 \mathrm{~km}^{2}$. Number of individuals was identified by Atasagun and Aksoy (2018) as 5672. Atasagun and Aksoy (2018) indicated that the species had a quite isolated distribution between Erciyes and Y1lanlı mountains of Kayseri; it was an endemic species under the threat of extinction mostly because of anthropogenic effects, animal grazing, stone quarry activities, Erciyes Mountain master plan, negative impacts of seasonal conditions based on altitude of spread zones, use of plant seeds by Oxycarenus sp. of Heteroptera suborder as nutrient and all these issues reduced formation of new individuals and negatively influenced the growth and development of the population.

C. amaena is rich in phenolics and flavonoids, thus has a strong antioxidant activity. Plants can be used as raw and processed food preservers and natural additives in 
pharmaceuticals, alternative medicine and natural treatment (Albayrak et al., 2017). $C$. amaena is under the threat of extinction and thus urgent measures should be taken to prevent extinction and for propagation of the species. Conservation is the effective storage of the diversity in the gene pool until its actual or potential use, and the introduction of this genetic diversity into the use of humanity. There are two primary conservation systems including in situ and ex situ conservation (Şehirali et al., 2015). In situ conservation means preservation of natural resources in their own habitats. However, ex situ conservation has become the most common practice for the conservation of plant genetic sources (Şehirali et al., 2015). Within the scope of ex situ conservation, in vitro tissue culture techniques are used. In recent years, several endangered and endemic species have been propagated and preserved from quite small quantity of plant material through these techniques without any significant impacts on wild populations (Erdağ and Emek, 2005a, b).

In previous studies, successful in vitro regeneration of Centaurea species were achieved from leaf, hypocotyl, cotyledon, node, soot tips, inflorescence stem parts-like explants with the aid of different cytokinin and auxin sources (Mallon et al., 2010; Aydoğan and Erdağ, 2015; Atalay and Erişen, 2017; Türkoğlu et al., 2018). In the different studies related to Centaurea species, the most commonly used cytokinins were BAP, kinetin, zeatin, TDZ and N6-(2-isopentyl) adenine (2-iP). Generally, BAP has been reported as the most efficient source of cytokinins for in vitro propagation of Centaurea species (Cuenca and Amo-Marco, 2000; Curkovic-Perica, 2003; Mallon et al., 2010; Atalay and Erişen, 2017). While the lowest response was obtained from zeatin, 2-iP and kinetin-containing media in C. ultreiae and from TDZ and kinetincontaining media in $C$. lycaonica, the use of kinetin was successful in $C$. paui (Cuenca et al., 1999) and $C$. tchihatcheffii (Ozel et al., 2006). In recent years, meta-topolin has been used to promote in vitro shoot regeneration as an alternative cytokinin source (Dimitrova et al., 2016). The use of $m \mathrm{~T}$ as a cytokinin source in Centaurea species have not been reported before and there are no studies about in vitro regeneration of Centaurea amaena. Therefore, this study was conducted to produce an efficient in vitro regeneration method for Centaurea amaena and the effectiveness of BAP, TDZ and $m$ T as a source of cytokinins was examined.

\section{Materials and methods}

\section{Plant material and achene sterilization}

Centaurea amaena Boiss \& Balansa was used as the plant material of the present study. Mature seeds of the species were collected in limited numbers from the natural habitat, Y1lanlı Mountain (Kayseri-Turkey), and seeds were preserved at $+4{ }^{\circ} \mathrm{C}$ for later uses in further analyses. All experimental procedures were conducted at Tissue Culture Laboratory of Field Crops Department at Erciyes University Agricultural Faculty. Sterile distilled water and $50 \%$ diluted $\mathrm{H}_{2} \mathrm{SO}_{4}$ were used for surface sterilization of the seeds. Seeds were initially kept in this solution for a minute, rinsed through sterile distilled water, kept again in 50\% diluted commercial bleach (ACE) in a magnetic stirrer for 10 min and finally rinsed through sterile distilled water three times and were germinated in sterile petri dishes with MSO media containing MS mineral salt and vitamins, $3 \%$ sucrose and $0.7 \%$ agar. About $15-20$ seeds were placed into each magenta vessel (Sigma-Aldrich, $77 \times 77 \times 97$ ). 


\section{Indirect organogenesis}

The cotyledon obtained from 2-weeks-old seedlings and leaves from about 1-monthold seedlings were used as explants for indirect organogenesis. Explants were cultured in MSO media containing different concentrations of TDZ $(0.3-1.2 \mathrm{mg} / \mathrm{l})$, BAP (1$\left.4 \mathrm{mg} \mathrm{L}^{-1}\right)$ or $m \mathrm{~T}\left(0.5-4 \mathrm{mg} \mathrm{L}^{-1}\right)$ alone or in combination with NAA $\left(0.5 \mathrm{mg} \mathrm{L}^{-1}\right)$. About 7-8 weeks after the initiation of culture processes, callus induction ratio (\%), shoot regeneration frequency $(\%)$ and number of shoots per explant were determined (Fig. 1A).

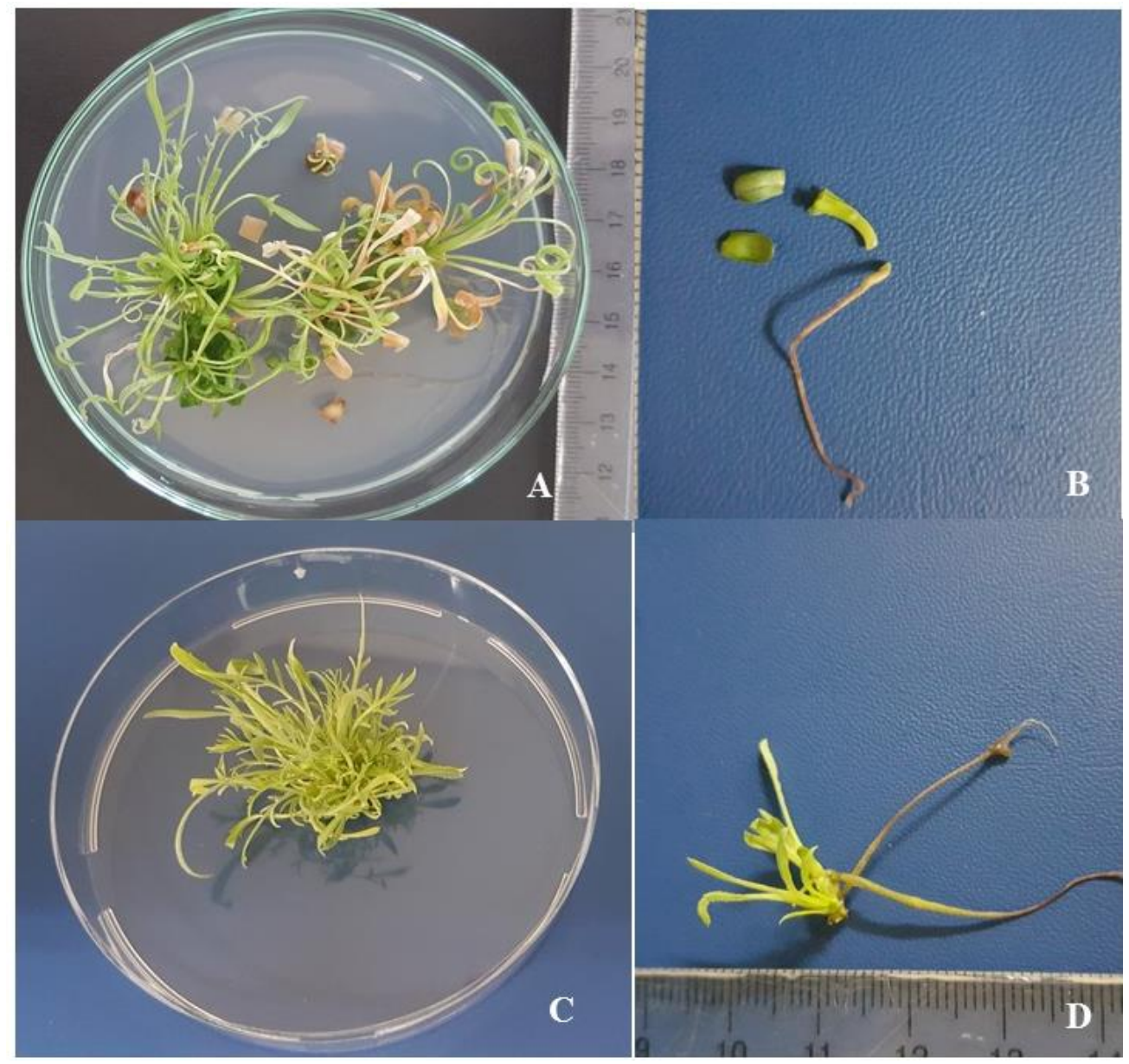

Figure 1. In vitro propagation and rooting of Centaurea amaena. A - Indirect organogenesis from cotyledon explant on MSO medium supplemented with $4 \mathrm{mg} \mathrm{L}^{-1} \mathrm{mT}, \mathrm{B}$ - Isolation of cotyledon node explant, $C$ - Axillary shoot regeneration form cotyledon node explant on MSO medium supplemented with $4 \mathrm{mg} \mathrm{L}^{-1} \mathrm{mT}, \mathrm{D}$ - Root formation of Centaurea amaena

\section{Axillary shoot regeneration}

Cotyledon node explants were isolated from the plantlets about 15-20 days after initiation of germination processes and were cultured in Magenta Vessels with MSO media containing different concentrations of TDZ (0.3-1.2 $\left.\mathrm{mg} \mathrm{L}^{-1}\right)$, BAP (1-4 mg L-1) or $m \mathrm{~T}\left(0.5-4 \mathrm{mg} \mathrm{L}^{-1}\right)$ with or without $0.5 \mathrm{mg} \mathrm{L}^{-1} \mathrm{NAA}$ (Fig. 1B-C). About 7-8 weeks after the initiation of culture processes, shoot regeneration frequency and number of shoots per explant parameters were determined. 


\section{Rooting}

Regenerated shoots were rooted in half-strength MS media containing $0.5,1$ or $2 \mathrm{mg} \mathrm{L}^{-1} \mathrm{IBA}$, $3 \%$ sucrose, solidified with $0.7 \%$ agar (Fig. 1D).

\section{Experimental conditions}

Entire sterile processes were conducted in a sterile cabin with a hepa-filter and horizontal air flow. Before the initiation of the sterile processes, the cabin was whipped with 96\% ethyl alcohol, the cabin was then left open for 20 min and sterilized under UV light. All tools, equipment, distilled water and growth media used in this study were sterilized in an autoclave under standard conditions $\left(1.2\right.$ atm pressure, $121^{\circ} \mathrm{C}$ temperature, $20 \mathrm{~min}$ ). Growth medium $\mathrm{pH}$ values were arranged as between 5.5-5.8 before agar supplementation. All cultures were grown under 16:8 light:dark photoperiod, $22 \pm 2{ }^{\circ} \mathrm{C}$ temperature and 3000 lux light intensity.

\section{Data analysis}

Experiments were conducted at completely randomized design with 4 replications. Each replication had 6 (for cotyledon node) or 10 (leaf and cotyledon) explants. Before variance analysis, percentiles were subjected to "arcsine" transformation. Variance analysis was performed with SPSS software. Means were compared with the aid of Duncan's multiple range test.

\section{Results and discussion}

\section{Indirect organogenesis}

For plant regeneration through organogenesis in $C$. amaena, cotyledon and leaves taken from the plantlets obtained from sterile seeds were cultured in 20 different media containing different concentrations of BAP, TDZ or $m \mathrm{~T}$ alone or in combination with NAA. About 7-8 weeks after the initiation of culture processes, callus induction ratio, shoot regeneration frequency and number of shoots per explant were determined. Callus induction ratios varied between $50-100 \%$. While type of explant did not have any significant effects on callus induction ratios, PGR (plant growth regulator) concentrations and combinations had significant effects on callus induction ratios $(\mathrm{P}<0.01)$. While the greatest callus induction ratios were obtained from BAP, BAPNAA, $m$ T-NAA, TDZ and TDZ-NAA-containing treatments, the lowest callus induction ratios were obtained from only $m \mathrm{~T}$-containing treatments (Fig. 2). Similarly, Atalay and Erişen (2017) also indicated that callus induction ratios in Centaurea lycaonica varied with the PGRs and reported high ratios for BAP-NAA and TDZ-NAA combinations. Researchers also identified differences in callus morphology of $C$. lycaonica based on PGR type and combinations.

PGRs and PGR $\times$ explant interactions had significant effects on shoot regeneration ratios and number of shoots per explant. Shoot regeneration frequencies varied between $0.00-57.50 \%$ in cotyledon explants and between $0.00-62.50 \%$ in leaf explant (Table 1). In both types of explants, callus induction was observed but shoot regeneration was not observed in TDZ-containing media. Similarly, Atalay and Erişen (2017) in Centaurea lycaonica and Aydoğan and Erdăg (2015) in Centaurea zeybekii, reported callus induction but no shoot regeneration in TDZ-containing media. In addition, Kazeroonian 
et al. (2018) indicated that type of cytokinin affected shoot regeneration and TDZ promoted callus induction rather than shoot regeneration in Chrysanthemum morifolium petiole explant. Dewir et al. (2018) reported that TDZ may result in various anomalies including inhibition of shoot proliferation, shoot elongation, etc., and indicated low TDZ concentrations, pulse treatment or short-duration TDZ treatments as efficient strategies to eliminate such anomalies. However, TDZ was also indicated as a strong synthetic cytokinin-like substance for shoot regeneration in several plant species (Erişen et al., 2011; Yorgancilar and Erişen, 2011; Uzun et al., 2014).

Table 1. Effects of PGRs on adventitious shoot regeneration from cotyledon and leaf explants of Centaurea amaena

\begin{tabular}{|c|c|c|c|c|}
\hline \multirow[t]{2}{*}{ PGRs } & \multicolumn{2}{|c|}{$\begin{array}{c}\text { Shoot regeneration } \\
\text { frequency }(\%)\end{array}$} & \multicolumn{2}{|c|}{ Number of shoots per explant } \\
\hline & Cotyledon & Leaf & Cotyledon & Leaf \\
\hline $1 \mathrm{mg} \mathrm{L}^{-1} \mathrm{BAP}$ & $40.00 \mathrm{ab}^{*}$ & $40.00 \mathrm{bcd}^{*}$ & $2.427 \mathrm{ef}^{*}$ & $1.775 \mathrm{gh}^{*}$ \\
\hline $2 \mathrm{mg} \mathrm{L}^{-1} \mathrm{BAP}$ & $30.00 \mathrm{bc}$ & $50.00 \mathrm{ab}$ & $3.125 \mathrm{~cd}$ & $3.997 \mathrm{ab}$ \\
\hline $4 \mathrm{mg} \mathrm{L}^{-1} \mathrm{BAP}$ & $22.50 \mathrm{~cd}$ & $47.50 \mathrm{ab}$ & $1.825 \mathrm{f}$ & $3.082 \mathrm{~cd}$ \\
\hline $1 \mathrm{mg} \mathrm{L}^{-1} \mathrm{BAP}+0.5 \mathrm{mg} \mathrm{L}^{-1} \mathrm{NAA}$ & $45.00 \mathrm{ab}$ & $62.50 \mathrm{a}$ & $2.052 \mathrm{f}$ & $3.930 \mathrm{ab}$ \\
\hline $2 \mathrm{mg} \mathrm{L}^{-1} \mathrm{BAP}+0.5 \mathrm{mg} \mathrm{L}^{-1} \mathrm{NAA}$ & $25.00 \mathrm{~cd}$ & $42.50 \mathrm{a}-\mathrm{d}$ & $1.125 \mathrm{~g}$ & $2.770 \mathrm{c}-\mathrm{f}$ \\
\hline $4 \mathrm{mg} \mathrm{L}^{-1} \mathrm{BAP}+0.5 \mathrm{mg} \mathrm{L}^{-1} \mathrm{NAA}$ & $15.00 \mathrm{~d}$ & $45.00 \mathrm{abc}$ & $1.042 \mathrm{~g}$ & 2.875 cde \\
\hline $0.5 \mathrm{mg} \mathrm{L}^{-1} m \mathrm{~T}$ & $40.00 \mathrm{ab}$ & $47.50 \mathrm{ab}$ & $3.265 \mathrm{bcd}$ & $1.415 \mathrm{~h}$ \\
\hline $1 \mathrm{mg} \mathrm{L}^{-1} m \mathrm{~T}$ & $55.00 \mathrm{a}$ & $27.50 \mathrm{~cd}$ & $4.152 \mathrm{a}$ & $3.375 \mathrm{bc}$ \\
\hline $2 \mathrm{mg} \mathrm{L}^{-1} m \mathrm{~T}$ & $37.50 \mathrm{ab}$ & $25.00 \mathrm{~d}$ & $3.227 \mathrm{~cd}$ & $2.832 \mathrm{cde}$ \\
\hline $4 \mathrm{mg} \mathrm{L}^{-1} m \mathrm{~T}$ & $55.00 \mathrm{a}$ & $50.00 \mathrm{ab}$ & $3.965 \mathrm{a}$ & $4.132 \mathrm{a}$ \\
\hline $0.5 \mathrm{mg} \mathrm{L}^{-1} m \mathrm{~T}+0.5 \mathrm{mg} \mathrm{L}^{-1} \mathrm{NAA}$ & $55.00 \mathrm{a}$ & $25.00 \mathrm{~d}$ & $2.902 \mathrm{de}$ & $2.290 \mathrm{efg}$ \\
\hline $1 \mathrm{mg} \mathrm{L}^{-1} m \mathrm{~T}+0.5 \mathrm{mg} \mathrm{L}^{-1} \mathrm{NAA}$ & $57.50 \mathrm{a}$ & $55.00 \mathrm{ab}$ & $3.927 \mathrm{ab}$ & $3.117 \mathrm{~cd}$ \\
\hline $2 \mathrm{mg} \mathrm{L}^{-1} m \mathrm{~T}+0.5 \mathrm{mg} \mathrm{L}^{-1} \mathrm{NAA}$ & $40.00 \mathrm{ab}$ & $27.50 \mathrm{~cd}$ & $3.970 \mathrm{a}$ & $2.082 \mathrm{fgh}$ \\
\hline $4 \mathrm{mg} \mathrm{L}^{-1} m \mathrm{~T}+0.5 \mathrm{mg} \mathrm{L}^{-1} \mathrm{NAA}$ & $47.50 \mathrm{ab}$ & $57.50 \mathrm{ab}$ & $3.657 \mathrm{abc}$ & $2.392 \mathrm{~d}-\mathrm{g}$ \\
\hline $0.3 \mathrm{mg} \mathrm{L}^{-1} \mathrm{TDZ}$ & $0 \mathrm{e}$ & $0 \mathrm{e}$ & $0 \mathrm{~h}$ & $0_{1}$ \\
\hline $0.6 \mathrm{mg} \mathrm{L}^{-1} \mathrm{TDZ}$ & $0 \mathrm{e}$ & $0 \mathrm{e}$ & $0 \mathrm{~h}$ & 01 \\
\hline $1.2 \mathrm{mg} \mathrm{L}^{-1} \mathrm{TDZ}$ & $0 \mathrm{e}$ & $0 \mathrm{e}$ & $0 \mathrm{~h}$ & 01 \\
\hline $0.3 \mathrm{mg} \mathrm{L}^{-1} \mathrm{TDZ}+0.5 \mathrm{mg} \mathrm{L}^{-1} \mathrm{NAA}$ & $0 \mathrm{e}$ & $0 \mathrm{e}$ & $0 \mathrm{~h}$ & 01 \\
\hline $0.6 \mathrm{mg} \mathrm{L}^{-1} \mathrm{TDZ}+0.5 \mathrm{mg} \mathrm{L}^{-1} \mathrm{NAA}$ & $0 \mathrm{e}$ & $0 \mathrm{e}$ & $0 \mathrm{~h}$ & 01 \\
\hline $1.2 \mathrm{mg} \mathrm{L}^{-1} \mathrm{TDZ}+0.5 \mathrm{mg} \mathrm{L}^{-1} \mathrm{NAA}$ & $0 \mathrm{e}$ & $0 \mathrm{e}$ & $0 \mathrm{~h}$ & 01 \\
\hline
\end{tabular}

*Values within a column followed by different letters are significantly different at 0.05 significance level using Duncan's multiple range test

The greatest numbers of shoots per explant were obtained from $1 \mathrm{mg} \mathrm{L}^{-1} m \mathrm{~T}, 4 \mathrm{mg} \mathrm{L}^{-1}$ $m \mathrm{~T}, 1-2$ or $4 \mathrm{mg} \mathrm{L}^{-1} m \mathrm{~T}+0.5 \mathrm{mg} \mathrm{L}^{-1} \mathrm{NAA}$ treatments in cotyledon explants and from $4 \mathrm{mg} \mathrm{L}^{-1} m \mathrm{~T}, 2 \mathrm{mg} \mathrm{L}^{-1} \mathrm{BAP}$ and $1 \mathrm{mg} \mathrm{L}^{-1} \mathrm{BAP}+0.5 \mathrm{mg} \mathrm{L}^{-1} \mathrm{NAA}$ treatments in leaf explants (Table 1). Optimum PGR type and concentration varied with explant type. Similarly, Erişen et al. (2011) reported differences in shoot regeneration of explants based on PGR concentrations and combinations in Astragalus cariensis. Success of a culture is influenced by type and concentration of applied cytokinin since cytokinin uptake, transport and metabolism varied with the plant species and cytokinin interacted with endogenous cytokinin of the explants (Magyar-Tabori et al., 2010). 


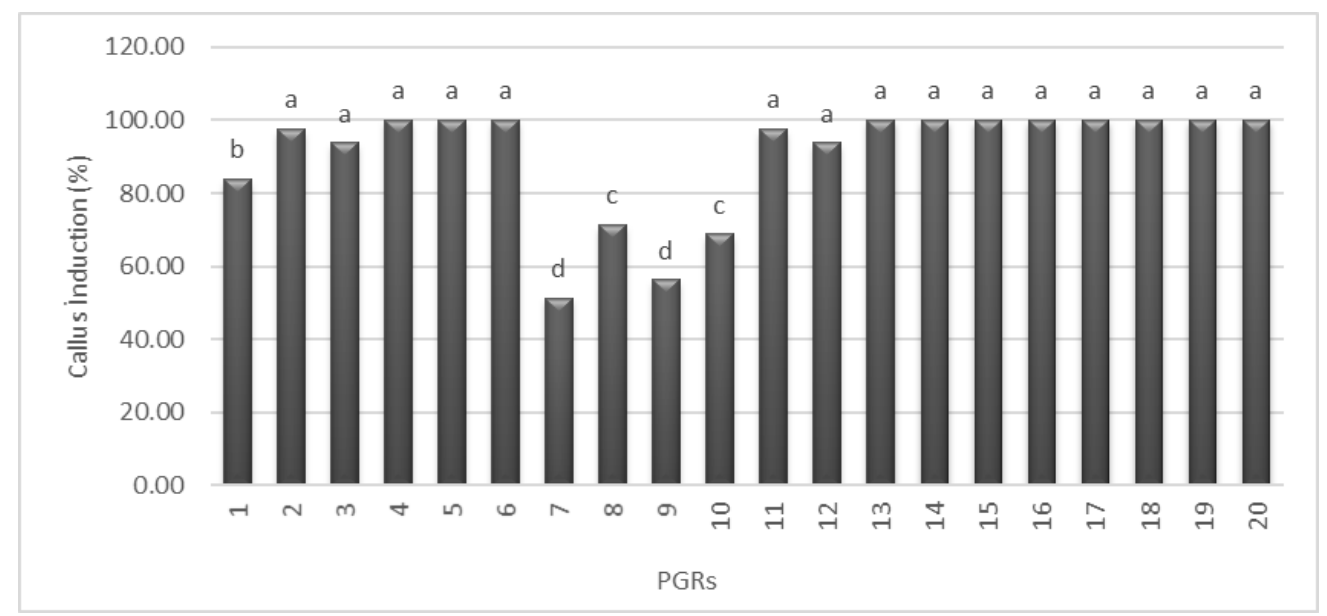

Figure 2. Effects of different PGR concentrations and combinations on callus induction ratios.

*Values within a column followed by different letters are significantly different at 0.05 significance level using Duncan's multiple range test. $1: 1 \mathrm{mg} \mathrm{L}^{-1} B A P ; 2: 2 \mathrm{mg} \mathrm{L}^{-1} B A P ; 3$ : $4 m g L^{-1} B$ AP; 4: $1 \mathrm{mg} L^{-1} B A P+0.5 m g L^{-1} N A A ; 5: 2 m g L^{-1} B A P+0.5 m g L^{-1} N A A, 6: 4 m g L^{-}$ ${ }^{1} B A P+0.5 m g L^{-1} N A A$, 7: $0.5 m g L^{-1} m T ; 8: 1 m g L^{-1} m T$; 9: $2 m g L^{-1} m T$; 10: $4 m g L^{-1} m T$; 11: $0.5 \mathrm{mg} \mathrm{L}^{-1} m T+0.5 \mathrm{mg} \mathrm{L}^{-1} N A A ; 12: 1 \mathrm{mg} \mathrm{L}^{-1} m T+0.5 \mathrm{mg} \mathrm{L}^{-1} \mathrm{NAA} ; 13: 2 \mathrm{mg} \mathrm{L}^{-1}$ $m T+0.5 m g L^{-1} N A A ; 14: 4 m g L^{-1} m T+0.5 m g L^{-1} N A A ; 15: 0.3 m g L^{-1} T D Z ; 16: 0.6 m g L^{-1}$ TDZ; 17: $1.2 \mathrm{mg} \mathrm{L}^{-1} \mathrm{TDZ}$; 18: $0.3 \mathrm{mg} \mathrm{L}^{-1} \mathrm{TDZ}+0.5 \mathrm{mg} \mathrm{L}^{-1} \mathrm{NAA}$; 19: $0.6 \mathrm{mg} \mathrm{L}^{-1}$

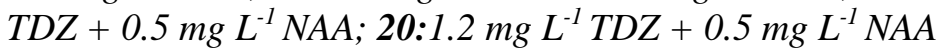

\section{Axillary shoot regeneration}

PGRs had significant effects on shoot regeneration frequency and number of shoots per explant $(\mathrm{P}<0.01)$. Shoot regeneration frequency of cotyledon node explants varied between $12.50-87.50 \%$ and the greatest shoot regeneration frequency was obtained from BAP, BAP-NAA, $m \mathrm{~T}$ and $m \mathrm{~T}$-NAA treatments (Table 2). The greatest number of shoots per explant (9.975 shoots) was obtained from $4 \mathrm{mg} \mathrm{L}^{-1} m \mathrm{~T}$ treatment and followed by $2 \mathrm{mg} \mathrm{L}^{-1} m \mathrm{~T}$ and $0.5-1 \mathrm{mg} \mathrm{L}^{-1} m \mathrm{~T}$. Only $m \mathrm{~T}$-containing media had greater number of shoots per explant than BAP and TDZ-containing media. When the BAPcontaining media were assessed in themselves, it was observed that the greatest number of shoots per explant (3.582 shoots) was obtained from $2 \mathrm{mg} \mathrm{L}^{-1}$ BAP treatment. BAP was also indicated as an appropriate cytokinin for axillary shoot regeneration in shoot apices of Centaurea ultreia (Mallon et al., 2010) and node explants of Centaurea lycaonica (Atalay and Erişen, 2017). Similarly, in present study, BAP-containing media were found to be more efficient than TDZ, however just $m$ T-containing media were identified as the most efficient for axillary shoot regeneration from cotyledon node. There were not any studies in literature about the use of $m \mathrm{~T}$ as a source of cytokinin in Centaurea species, but it was reported in studies on cassava, pelargonium and sweet basil that $m \mathrm{~T}$ improved in vitro shoot proliferation and shoot quality (Wojtania, 2010; Köszeghi et al., 2014; Chauhan and Taylor, 2018). Fajinmi et al. (2014) demonstrated $m \mathrm{~T}$ as a quite active and an alternative cytokinin to BAP and other cytokinins for shoot regeneration in shoot tip explant of Coleonema album. Such an efficiency of $m \mathrm{~T}$ is mostly attributed to chemical structure allowing production of O-glucoside metabolites from hydroxyl group of side chain of $m \mathrm{~T}$ and rapid translocation of it in plant tissues (Fajinmi et al., 2014). In only $m \mathrm{~T}$-containing media, number of shoots per explant increased with increasing $m \mathrm{~T}$ doses. Dimitrova et al. (2016) also reported increasing 
regenerations with increasing $m \mathrm{~T}$ doses in Pyrus communis. As compared to only $m \mathrm{~T}$ containing media, number of shoots per explant decreased in $m$ T-NAA combinations. But contrary to present findings, $m$ T-NAA combinations increased the number of shoots per explant in Coleonema album and Huernia hystrix (Fajinmi et al., 2014; Amoo and Van Staden, 2013). Such differences were mainly attributed to synergic, antagonistic and additional interactions between auxins and cytokinin based on plant species and type of tissue (Coenen and Lomax, 1997).

Table 2. Effects of PGRs on axillary shoot regeneration form cotyledon node explant of Centaurea amaena

\begin{tabular}{|c|c|c|}
\hline PGRs & Shoot regeneration frequency $(\%)$ & Number of shoots per explant \\
\hline $1 \mathrm{mg} \mathrm{L}^{-1} \mathrm{BAP}$ & $87.50 \mathrm{a}^{*}$ & $2.867 \mathrm{ef}^{*}$ \\
\hline $2 \mathrm{mg} \mathrm{L}^{-1} \mathrm{BAP}$ & $87.50 \mathrm{ab}$ & $3.582 \mathrm{de}$ \\
\hline $4 \mathrm{mg} \mathrm{L}^{-1} \mathrm{BAP}$ & $83.33 \mathrm{abc}$ & $2.445 \mathrm{f}$ \\
\hline $1 \mathrm{mg} \mathrm{L}^{-1} \mathrm{BAP}+0.5 \mathrm{mg} \mathrm{L}^{-1} \mathrm{NAA}$ & $83.33 \mathrm{abc}$ & 3.000 ef \\
\hline $2 \mathrm{mg} \mathrm{L}^{-1} \mathrm{BAP}+0.5 \mathrm{mg} \mathrm{L}^{-1} \mathrm{NAA}$ & $83.33 \mathrm{abc}$ & $2.750 \mathrm{f}$ \\
\hline $4 \mathrm{mg} \mathrm{L}^{-1} \mathrm{BAP}+0.5 \mathrm{mg} \mathrm{L}^{-1} \mathrm{NAA}$ & $87.50 \mathrm{a}$ & $2.685 \mathrm{f}$ \\
\hline $0.5 \mathrm{mg} \mathrm{L}^{-1} \mathrm{mT}$ & $87.50 \mathrm{ab}$ & $5.375 \mathrm{c}$ \\
\hline $1 \mathrm{mg} \mathrm{L}^{-1} m \mathrm{~T}$ & $87.50 \mathrm{ab}$ & $5.165 \mathrm{c}$ \\
\hline $2 \mathrm{mg} \mathrm{L}^{-1} m \mathrm{~T}$ & $83.33 \mathrm{ab}$ & $6.250 \mathrm{~b}$ \\
\hline $4 \mathrm{mg} \mathrm{L}^{-1} m \mathrm{~T}$ & $70.83 \mathrm{a}-\mathrm{d}$ & $9.975 \mathrm{a}$ \\
\hline $0.5 \mathrm{mg} \mathrm{L}^{-1} m \mathrm{~T}+0.5 \mathrm{mg} \mathrm{L}^{-1} \mathrm{NAA}$ & $66.66 \mathrm{~b}-\mathrm{e}$ & $2.750 \mathrm{f}$ \\
\hline $1 \mathrm{mg} \mathrm{L}^{-1} m \mathrm{~T}+0.5 \mathrm{mg} \mathrm{L}^{-1} \mathrm{NAA}$ & $74.99 \mathrm{abc}$ & $4.137 \mathrm{~d}$ \\
\hline $2 \mathrm{mg} \mathrm{L}^{-1} m \mathrm{~T}+0.5 \mathrm{mg} \mathrm{L}^{-1} \mathrm{NAA}$ & $83.33 \mathrm{abc}$ & $2.750 \mathrm{f}$ \\
\hline $4 \mathrm{~m} \mathrm{mg} \mathrm{L}^{-1} m \mathrm{~T}+0.5 \mathrm{mg} \mathrm{L}^{-1} \mathrm{NAA}$ & 58.33 cde & 3.000 ef \\
\hline $0.3 \mathrm{mg} \mathrm{L}^{-1} \mathrm{TDZ}$ & $29.17 \mathrm{fg}$ & $0.875 \mathrm{~g}$ \\
\hline $0.6 \mathrm{mg} \mathrm{L}^{-1} 1 \mathrm{TDZ}$ & $37.49 \mathrm{ef}$ & $1.375 \mathrm{~g}$ \\
\hline $1.2 \mathrm{mg} \mathrm{L}^{-1} \mathrm{TDZ}$ & $41.67 \mathrm{def}$ & $1.083 \mathrm{~g}$ \\
\hline $0.3 \mathrm{mg} \mathrm{L}^{-1} \mathrm{TDZ}+0.5 \mathrm{mg} \mathrm{L}^{-1} \mathrm{NAA}$ & $12.50 \mathrm{~g}$ & $0.750 \mathrm{~g}$ \\
\hline $0.6 \mathrm{mg} \mathrm{L}^{-1} \mathrm{TDZ}+0.5 \mathrm{mg} \mathrm{L}^{-1} \mathrm{NAA}$ & $12.50 \mathrm{~g}$ & $0.750 \mathrm{~g}$ \\
\hline $1.2 \mathrm{mg} \mathrm{L}^{-1}+0.5 \mathrm{mg} \mathrm{L}^{-1} \mathrm{NAA}$ & $25.00 \mathrm{fg}$ & $0.833 \mathrm{~g}$ \\
\hline
\end{tabular}

*Values within a column followed by different letters are significantly different at 0.05 significance level using Duncan's multiple range test

\section{Rooting}

Regenerated shoots were rooted in $1 / 2$ MS media containing $0.5,1$ or $2 \mathrm{mg} \mathrm{L}^{-1}$ IBA. About 5-6 weeks after the initiation of culture processes, percentage of root-forming shoots were respectively identified as $33.33,38.89$ and $50.00 \%$. IBA was also identified as an available auxin for promotion of rooting of regenerated shoots in Centaurea rupestris and Centaurea arifolia species (Curkovic-Perica, 2003; Yüzbaşığlu et al., 2012).

\section{Conclusions}

The primary target of the present study was to investigate regeneration potential of Centaurea amaena. In present experiments, 4 shoots per explant were obtained from 
cotyledons and leaves and 10 shoots per explant were obtained from the cotyledon nodes of $C$. amaena. It was concluded based on present findings that $m \mathrm{~T}$ and BAP were efficient cytokinins for in vitro regeneration of $C$. amaena. Regenerated shoots were rooted in half-strength MS medium supplemented with IBA. A simple and efficient propagation procedure was developed in this study for the critically endangered species C. amaena. This procedure could be useful for the in situ and ex situ conservation of this valuable genetic source. However, the genetic stability of regenerated plants must be verified using molecular markers in further studies.

Acknowledgements. This study was supported by the Scientific Research Foundation of Erciyes University (Project Number: FYL-2016-6308). This paper has been prepared from Master's Thesis of Özge EKİNCİ.

\section{REFERENCES}

[1] Albayrak, S., Atasagun, B., Aksoy, A. (2017): Comparison of phenolic components and biological activities of two Centaurea sp. obtained by three extraction techniques. Asian Pacific Journal of Tropical Medicine 10(6): 599-606.

[2] Amoo, S. O., Van Staden, J. (2013): Influence of plant growth regulators on shoot proliferation and secondary metabolite production in micropropagated Huernia hystrix. Plant Cell, Tissue and Organ Culture (PCTOC) 112(2): 249-256.

[3] Atalay, E., Erisen, S. (2017): High frequency regeneration of critically endangered endemic plant Centaurea lycaonica. - Fresenius Environmental Bulletin 26(11): 63566363.

[4] Atasagun, B., Aksoy, A. (2018): Autecology and conservation biology of Centaurea amaena (Asteraceae). - JAPS Journal of Animal \& Plant Sciences 28(1).

[5] Atasagun, B., Aksoy, A., Martin, E., Uzun, O. (2013): Morphological, anatomical, palynological, karyological and autecological characters of Centaurea amaena Boiss. \& Balansa [Sect. Phalolepis (Centaurea/Asteraceae)]. - Plant Systematics and Evolution 299(9): 1761-1767. DOI: 10.1007/s00606-013-0831-9.

[6] Aydoğan, S. K., Erdağ, B. (2015): Callus induction and adventitious shoot regeneration of Centura zeybekii endangered endemic plant. - Nevşehir Bilim ve Teknoloji Dergisi, 4(2): $1-8$.

[7] Chauhan, R. D., Taylor, N. J. (2018): Meta-topolin stimulates de novo shoot organogenesis and plant regeneration in cassava. - Plant Cell, Tissue and Organ Culture (PCTOC) 132(1): 219-224. DOI: 10.1007/s11240-017-1315-3.

[8] Coenen, C., Lomax, T. L. (1997): Auxin-cytokinin interactions in higher plants: old problems and new tools. - Trends in plant science 2(9): 351-356.

[9] Cuenca, S., Amo-Marco, J.B. (2000): In vitro propagation of Centaurea spachii from inflorescence stems. -Plant Growth Regulation 30: 99-103.

[10] Cuenca, S., Amo-Marco, J.B., Parra, R. (1999). Micropropagation from inflorescence stems of the Spanish endemic plant Centaurea paui Loscos ex Willk. (Compositae). Plant Cell Reports 18: 674-679.

[11] Curkovic-Perica, M. (2003): In vitro propagation of Centaurea rupestris L. - Acta Biologica Cracoviensia Series Botanica 45(2): 127-130.

[12] Dewir, Y. H., Naidoo, Y., da Silva, J. A. T. (2018): Thidiazuron-induced abnormalities in plant tissue cultures. - Plant Cell Reports 37(11): 1451-1470. https://doi.org/10.1007/s00299-018-2326-1. 
[13] Dimitrova, N., Nacheva, L., Berova, M. (2016): Effect of meta-topolin on the shoot multiplication of pear rootstock OHF-333 (Pyrus communis L.). - Hortorum CultusActa Scientiarum Polonorum 15: 43-53.

[14] Erdağ, B., Emek, Y. (2005a): In vitro adventitious shoot regeneration of Liquidambar orientalis Miller. - Journal of Biological Sciences 5(6): 805-808.

[15] Erdağ, B., Emek, Y. (2005b): In vitro micropropagation of Anthemis xylopoda O. Schwarz, a critically endangered species from Turkey. - Pakistan Journal of Biological Sciences 8(5): 691-695.

[16] Erişen, S., Atalay, E., Yorgancilar, M. (2011): The effect of thidiazuron on the in vitro shoot development of endemic Astragalus cariensis in Turkey. - Turkish Journal of Botany 35(5): 521-526. DOI: 10.3906/bot-1009-74.

[17] Fajinmi, O. O., Amoo, S. O., Finnie, J. F., Van Staden, J. (2014): Optimization of in vitro propagation of Coleonema album, a highly utilized medicinal and ornamental plant. South African Journal of Botany 94: 9-13. http://dx.doi.org/10.1016/j.sajb.2014.05.006.

[18] Kazeroonian, R., Mousavi, A., Jari, S. K., Tohidfar, M. (2018): Factors Influencing in Vitro Organogenesis of Chrysanthemum morifolium cv.'Resomee Splendid'. - Iranian Journal of Biotechnology 16(2): 133-139. DOI: 10.21859/ijb.1454.

[19] Köszeghi, S., Bereczki, C., Balog, A., Benedek, K. (2014). Comparing the effects of benzyladenine and meta-Topolin on sweet basil (Ocimum basilicum) micropropagation. Notulae Scientia Biologicae 6(4): 422-427. DOI: 10.1583/nsb649464.

[20] Magyar-Tabori, K., Dobranszki, J., da Silva, J. A. T., Bulley, S. M., Hudak, I. (2010): The role of cytokinins in shoot organogenesis in apple. - Plant Cell, Tissue and Organ Culture (PCTOC) 101(3): 251-267. DOI: 10.1007/s11240-010-9696-6.

[21] Mallon, R., Rodriguez-Oubina, J., Gonzalez, M. L. (2010): In vitro propagation of the endangered plant Centaurea ultreiae: assessment of genetic stability by cytological studies, flow cytometry and RAPD analysis. - Plant Cell, Tissue and Organ Culture (PCTOC) 101(1): 31-39. DOI: 10.1007/s11240-009-9659-y.

[22] Ozel, C. A., Khawar, K. M., Mirici, S., Ozcan, S., Arslan, O. (2006). Factors affecting in vitro plant regeneration of the critically endangered Mediterranean knapweed (Centaurea tchihatcheffii Fisch et. Mey). - Naturwissenschaften 93(10): 511-517. DOI: 10.1007/s00114-006-0139-5.

[23] Şehirali, S., Özgen, M., Karagöz, A., Sürek, M., Adak, S., Güvenç, İ., Tan, A., Burak, M., Kaymak, Ç. (2015): Bitki Genetik Kaynaklarının Korunma ve Kullanımı. http://www.zmo.org.tr/resimler/ekler/7e8e17134dd7083_ek.pdf (erişim tarihi: 25.08.2015).

[24] Türkoğlu, N., Özdemir, F.A., Keskin, N., Khawar, K.M. (2018): Efficient protocol for multiple micro-shoot regenetation from endanger, endemic and ornamental plant Centaurea fenzlii Reichardt. Fresenius Environmental Bulletin 27(2): 1076-1080.

[25] Uzun, S., İlbaş, A. İ., İpek, A., Arslan, N., Barpete, S. (2014): Efficient in vitro plant regeneration from immature embryos of endemic Iris sari and I. schachtii. - Turk J Agric For 38: 348-353. DOI: 10.3906/tar-1306-47.

[26] Wojtania, A. (2010): Effect of meta-topolin in vitro propagation of cultivars. - Acta Societatis Botanicorum Poloniae, 79(2), 101-106.

[27] Yorgancilar, M., Erisen, S. (2011): The effect of thidiazuron (TDZ) on shoot regeneration of Astragalus schizopterus. - Journal of Animal and Plant Sciences 21(3): 519-524.

[28] Yüzbaşıoğlu, E., Dalyan, E., Bona, M., Öz, G. (2012): In vitro propagation of endemic plant Centaurea arifola Boiss. Taxa. - IUFS Journal of Biology 71(2): 121-127. 